\title{
A 'Triangular' Relationship with the Great Powers: The Case of the post-Cold War Vietnam Balancing versus China and the USA
}

\author{
Leonid L. Kyianytsia \\ Ph.D. in Political Science, Research Fellow at the I. F. Kuras Institute of Political and Ethnic \\ Studies of the National Academy of Sciences of Ukraine (Kyiv, Ukraine) \\ E-mail: phukidides@gmail.com \\ https://orcid.org/0000-0002-0588-965X
}

Kyianytsia, Leonid L. (2019) A 'Triangular' Relationship with the Great Powers: The Case of the post-Cold War Vietnam Balancing versus China and the USA. Ukrainian Policymaker, Volume 5, 44-52. https://doi.org/10.29202/up/5/5

The present article attempts to analyze the case of Vietnam as a middle power caught in-between two potentially inimical greater states, viz. the United States of America and the People's Republic of China, in the aftermath of the Cold War, with a view to exploring the degree to which the former would have managed to maintain its relative independence in respect of each of the contending powers while drawing benefits from the relations with either of them.Making use of the multiple sources covering the presentday relations of Vietnam with both China and the U.S., the author argues that even though Vietnam had been confronted with several critical junctures wherein it may be motivated to fully align with either of the two powers, the country's leadership would maintain a relatively neutral position while participating in the structures of interdependence and integration involving both great powers under consideration. Several implications for Ukraine's international political strategy are thus foreshadowed in that respect.

Keywords: Vietnam, China, the United States of America, balancing, complex inter-dependence

Received: October 9, 2019; accepted: October 19, 2019

\section{Introduction}

The end of the global confrontation known as the Cold War (1948-1989) had become a watershed moment for erstwhile allies of the Soviet Union, which would henceforth have to try to carve out a new place for themselves in a rapidly changing world of international politics. Having emerged victorious from the Second Indochina War in 1975, the Socialist Republic in Vietnam appeared to be particularly threatened by the new international arrangements given that its previously generous financial and military-technological support from the USSR was

(C) Kyianytsia, Leonid L., 2019 
cut off, while both the U.S. and the People's Republic of China (PRC) would have hardly been amicably disposed toward their recent enemy in Hanoi (cf. Wong, 2002; Nguyen, 2016). Consequently, the survival and relative strength of the contemporary Vietnam, as well as its ability to strike seemingly beneficial deals with both Washington and Beijing, may be seen as a rather counter-intuitive outcome of the post-Cold War dynamic of international relations in Indochina. Simultaneously, the case of Vietnam could be viewed in a comparative light as far as a relatively dissimilar situation of Ukraine is concerned: whereas the Vietnamese state had so far managed to align its 'multi-vectoral' foreign policy course with the tasks of state survival and development, the Ukrainian one would have become entangled in mutually contradictory political arrangements arising out of its multi-vectoral commitments of the 2000s and the 2010s, only to find itself facing the Russian Federation in 2014 without any direct assistance on the part of its 'strategic partners' in the West (Mearsheimer, 2014; Battle, 2015). Therefore, exploring the experience of Vietnam, for all the obvious differences in terms of political regime and social structure, could potentially enable one to elucidate the causes of Vietnam's relative success, and Ukraine's evident failure, as far as balancing two major powers' influence on one's own state while avoiding any direct bandwagoning to either of them may be involved.

With this in mind, the present article provides a comprehensive analysis of Vietnam's foreign policy strategy aimed to develop and implement a middle-of-the-road policy with regard to both U.S. and Chinese interests affecting the Vietnamese state. In doing so, the author draws upon the theoretical constructs derived from both the neo-realist and the neoliberal institutionalist paradigms in order to clarify the essence of Vietnam's international policy strategy in the post-Cold War era. More specifically, the three aspects that will have been of interest to the researcher in the context of this article are as follows: (1) the specific strategy of international balancing as employed by the Vietnamese leadership with respect to both China and the U.S.; (2) the role of the legacy of military-political confrontation with the United States of America and the People's Republic of China in Vietnam's international strategy concerning the two powers; and (3) the degree to which the complex interdependence arising out of economic and cultural ties with either China or the U.S. may have swayed Vietnam's foreign policy in that regard. Based on such considerations, the present article seeks to provide a background for a future in-depth study of the case of Ukraine in terms of the failure of its 'multi-vectoral' diplomacy with regard to the EU, Russia, and the U.S. in the early 2010s. Thus, the foundations for a comparative analysis of balancing efforts of middle states caught in-between greater powers in the post-Cold War era may be provided here.

\section{Methodological premises}

This research attempts to arrive at a synthesis of two major methodological approaches in the study of international relations, viz. neo-realism (Freyberg-Inan, 2004; Korab-Karpowicz, 2010; Mearsheimer, 2001) and neo-liberal institutionalism (Galbreath, 2008; Keohane, 2012; Jahn, 2013), by emphasizing a coterminous impact of structural disparities in the relevant states' relations of strategic interdependence, on the one hand, and of cooperative exchanges among the former as being part of the global system of international relations, on the other hand. As for the neo-realist concepts in studying international relations proper, one should refer first and foremost to those of balancing (itself resting upon a specific understanding of a distribution of capabilities observable within a given system of states; Odgaard, 2007), and of 
free riding versus bandwagoning, as being analytically useful for the purposes of this study. Whereas balancing implies that "states rely relentlessly both on arming and on imitating the successful military practices of peer competitors and rarely resort to alliances for their security" (Parent \& Rosato, 2015: 52), the notion of bandwagoning provides for an alternative logic within which the states feeling insecure would tend to attach themselves to alliances created by major powers, especially the ones that are able to successfully lay claim to international hegemony (Baviera, 2011). Accordingly, analyzing the case of Vietnam in the light of the aforementioned concepts would require exploring the extent to which its international political behavior might have featured the traits of each of the approaches implied above. In that sense, it would be possible to identify the correlation between such ideal types of the states' behavior in an anarchic international environment and Vietnam's actual behavior with respect to China and the U.S. after 1989.

The focus of the neo-liberal institutionalist thinking would instead be placed on the concept of complex interdependence having been allegedly born out of the nation-states' enlightened self-interest to provide for entrepreneurial competitiveness and general welfare of their citizens by developing and maintaining long-term relations of economic cooperation with one another (Sterling-Folker, 2002: 48-51). If one extends the concept in question to incorporate the aspects of cultural cooperation / affinity between the respective states, then it would be fruitful to characterize the possible situation of complex interdependence between Vietnam and the U.S. and/or Vietnam and China as exerting influence upon the Vietnamese state's readiness to develop cooperative relations with either of the two powers even beyond the requirements of ensuring its own security. If no evidence for such state of affairs may be obtained, then the null hypothesis will prevail, viz. one will have to admit that economic and cultural interdependence would play no tangible role in the context of Vietnam's relations with the two powers under consideration.

To summarize, the methodological basis for this article will take into account the need to verify the applicability of the concepts and theoretical constructs briefly explored above to the empirical case of Vietnam's interrelations with both the U.S. and the People's Republic of China in the post-Cold War political climate, in as much as it may be proven that Vietnam would have followed any of the courses of action hypothesized by the neo-realist scholars and/ or displayed any inclination to base its policy on any form of complex interdependence with either of the two greater powers in question.Hence the focus on the present case study will potentially contribute to testing the reliability of more or less abstract concepts in the discipline of International Relations per se.

\section{Vietnam's 'triangular' foreign policy after 1989: a general review}

The general considerations as to the character of Vietnam's international political strategy in the contemporary era should necessarily proceed from analyzing the Vietnamese state's specific measures and policies designed to address the urgent problem of re-configuring its international commitment after the end of the Cold War. As the fall of the Soviet Union and its international bloc would have constrained the room for maneuver available to the Vietnamese Communist Party (hereinafter referred to as the VCP), forcing it to make amends to the previous international political doctrine of the Socialist Republic of Vietnam (Vu, 2011; Abuza, 1996). The 1992 adoption of the Comprehensive Security Approach could thus be viewed as representing a first definitive statement of the balancing-oriented geo-political and geo-economic position of 
Vietnam that has already been mentioned above (Abuza, 1996). The key notions underscored in this VCP-approved document may accordingly be summarized as follows:

(a) The Vietnamese nation-state was to strive to develop mutually beneficial relations with all other nation-states, without prejudice to the fact whether those might have been "former enemies" or not (hereby signaling the readiness to negotiate with both the U.S. and the PRC);

(b) The government of Vietnam would renounce any dependence on the 'superpowers' and avoid any affiliation with both existing and future military alliances of any kind; and

(c) The economic development of Vietnam was to be designated as the utmost priority of the state's international relations, therefore providing for the focus on peaceful cooperation with the parties concerned (see Abuza, 1996: 409, for further details).

As one may see, the points noted afore would amount to a thorough revision of the pre1989 geopolitical positioning of Vietnam, with a newly non-confrontational and even neutralist policy approach being evidently devised to allow an in-depth rapprochement with both the PRC and the United States. The rationale behind such a step would be two-fold: on the one hand, Vietnam would want to relieve itself out of the international isolation it ended up in following the 1979 invasion of Cambodia / Kampuchea, which would become much more dire after the end of the Soviet support for Vietnam (Abuza, 1996); on the other hand, 1992 saw the first instance of maritime clashes between the Chinese and the Vietnamese naval forces over the territorial claims as to the Spratly archipelago, potentially presaging further tensions between the two states (Wong, 2002: 353-354).In addition, the development of the South Asian economic integration under the auspices of the Association of Southeast Asian Nations (ASEAN) would prove to be one of the fundamental stimuli for a subsequent re-alignment of Vietnam's foreign policy thinking: as noted by Le Mai, the country's Deputy Minister for Foreign Affairs in 1995 (at the time of the intense talks between the ASEAN and Vietnam concerning the latter's affiliation with the former), the Vietnamese leadership would assume that "we are now in an era where geo-economics is an overwhelming factor that enables us all to move beyond ideological boundaries in order to sustain mutually beneficial cooperation" (Abuza, 1996: 412). Consequently, the new configuration of Vietnam's foreign policy in the early 1990s would pursue the objective of drawing benefits from the emergent process of globalization and interdependence, rather than opposing it.

On the other hand, the focus on fostering international economic ties, which may be directly attributed to the push for strengthening Vietnam's economic capabilities in the new international context, was accompanied with the efforts aimed at developing the country's military and military technological potential, as expressed in the so-called 'just-enough' / 'sufficiency' doctrine (in Vietnamese, vùađủ; Elliott, 2012: 268). Accordingly, the VCP would admit to the possibility, and even necessity, of finding new partners in respect of getting access to new military technologies and equipment, with first China and then the U.S. destined to be considered for such cooperation. The problem of U.S. Army personnel missed in action (MIA) during the Second Indochina War had turned out to be one of key bones of contention in the context of restoring U.S.-Vietnam relations in the mid-1990s (Shoji, 2018). With the active participation and engagement of U.S. Senator John McCain, the United States and Vietnam would go on to re-establish formal diplomatic ties in 1995; however, in 1997 the VCP leadership would still lay bare its ongoing distrust of the U.S. by ruling that any future military-security cooperation with Washington should be limited to "three areas: military medicine; cooperation on military science and technology; and humanitarian assistance and disaster relief (HA/DR)" (Shoji, 2018: 4-5). 
The fear of the 1989-1991 revolutionary events in the Eastern bloc repeating themselves in Vietnam would have likewise made the VCP leadership rather reticent regarding the rapprochement with the United States: for instance, in 1994, the notion of a "peaceful evolution by hostile forces" was introduced into the official vocabulary to denote a perceived threat of the internal subversion of the socialist regime in Vietnam as supposedly championed by the U.S. and the West in general ( Vu, 2011: 109). The primary partner of Vietnam in terms of military cooperation in the 1990s would prove to be the PRC as the two countries had carried out a range of high-profile exchanges at the inter-military cooperation level, in spite of the still unresolved problem of territorial claims in the South China Sea - a unique situation for the contemporary history. A peculiar fact worth mentioning in this context is that each successive President of Vietnam would have his first foreign visit to Beijing from 1992 on (Nguyen, 2016: 38). Thus, in spite of the aforementioned territorial claims-related disagreements between Beijing and Hanoi, the VCP leadership would signal its readiness to demonstrate its ideological rapport with the Chinese Communist Party (CCP), which could be further explained in the light of the abovementioned premonitions regarding the U.S.' alleged intent to subvert the Vietnamese government in a 1989-style manner. This may explicate the paradoxical fact of close ties between the two countries' militaries in the 1990s and the 2000s, in spite of the enduring legacy of the 1979 Sino-Vietnamese War and the 1992 Spratly conflict, with the PRC being perceived as a natural partner in opposing the West's liberal-democratic drive.

Nonetheless, in the 2000s, against the backdrop of the ongoing increase in China's assertiveness in the South China Sea (as expressed, among other things, in the 2009-2011 series of incidents related to Chinese naval border guards detaining or impounding multiple Vietnamese fishing boats and their crews; see Thayer, 2011: 357). Thus it would come as no surprise that from 2009 on, Vietnam would intensify its military-security cooperation with the USA beyond the limits earlier specified in 1997. In effect, even before that time, the Vietnamese government and military would have gradually acquiesced to more wide-ranging involvement with their U.S. counterparts. As an example, in June 2007, Robert Gates, thenSecretary for Defense, and Minister Nguyen Tan Dung, the head of the Vietnamese government, held talks on the problems of regional security cooperation and potential military-to-military exchanges (Lohman et al., 2012: 7). This would be followed by the December 2007 visit of Timothy Keating, the U.S. Admiral in charge of the Pacific Command, which was focused on developing ties between the U.S. and the Vietnamese naval forces (Manyin, 2008: 20) - a rather foreseeable course of events given the aggravation of the Sino-Vietnamese relations precipitated by the tensions in the South China Sea at that time. The foundations laid down in the course of those two visits would come to fruition in October 2008, with the first U.S.Vietnam Security Dialogue on Political, Security, and Defense Issues ushering in an era of closer cooperation on the relevant issues between the two parties (Manyin, 2010: 4).

It is worth noting that similar dialogue-oriented arrangements in Sino-Vietnamese relations were earlier put into effect in 2000, when the Sino-Vietnamese Joint Statement for Comprehensive Cooperation in the New Century had provided for the military-to-military consultation mechanism between Hanoi and Beijing (Nguyen, 2016: 169). However, unlike the latter, the 2008 U.S.-Vietnamese security dialogue would be carefully couched in terms of a "civilian-led" security relationship, with the role of the respective military contacts being purposefully downplayed (Manyin, 2010: 4). In that sense, one may surmise that Vietnam would have taken some measures of precaution to avoid drawing the ire of China 
in a rather sensitive period of the mutual relations. Furthermore, the period of 2005-2009 saw a substantial increase in the number of high-level military-to-military contacts between the Chinese and the Vietnamese militaries: whereas 11 Vietnamese delegations attended to various events and maneuvers in the PRC, 9 Chinese delegations would be sent to Vietnam in the same capacity (Thayer, 2011). Several rhetorical signals of Vietnam's desire to foster stronger military-to-military relations with China would be routinely given throughout those delegation exchanges. For example, during the 2009 visit of General Le Van Dung, then one of Vietnam's leading figures of the General Staff, the latter had expressed his hope that the conflicting territorial claims of Vietnam and China to the isles in the South China Sea might be resolved amicably to the effect that the two nations "will keep strengthening our relations... in order to fight the plots of the common enemy" (Nguyen, 2016: 171), the latter being a barely veiled reference to the USA. However, the tone of the Vietnamese military leadership would change drastically in the early 2010 s, when it became clear that China could hardly be disposed to offer any concessions to Vietnam in exchange for a joint anti-U.S. stance.

Instead, the emphasis on balancing China's influence in the South China Sea led Vietnam to countenance reaching out to the U.S. in a previously unprecedented way. Thus, in 2011, Vietnamese officers were for the first time admitted for training at the U.S. War College, while the new framework for the Defense Policy Dialogue (DPD) was instituted with the proviso for regular communications at the vice-ministerial level between Vietnam $\backslash$ s Ministry of Defense and the U.S. Department of Defense (Hiebert et al., 2014: 14). In a more concrete sense, the U.S. Congress allocated $\$ 1,1$ million in foreign military funding (FMF) for the needs of the Vietnamese military in 2011 (Manyin, 2012) as the U.S. Navy vessels were given opportunity to make port calls in the Camranh Bay for the purposes of being maintained and repaired there (with 5 U.S. Navy ships availing themselves of such opportunity in 2011-2012; Shoji, 2018: 8). At the same time, the Chinese navy had been given similar rights in 2001 already (Stern, 2005: 397), which would underscore the lack of readiness on the part of the Vietnamese leadership to renege on its prior agreements with its Chinese partners. Even in the circumstances of the May 2014 clash between the Vietnamese and the Chinese naval ships in the South China Sea, Vietnam's defense minister PhungQuang Thanh would still pay a visit to Beijing to try to hammer out a compromise solution with his Chinese counterpart (Thayer, 2014). Later in the 2010s, Vietnam would potentially demonstrate its implicit desire to move out of Beijing's orbit by increasing the intensity of the security ties with the United States. The most salient examples of such behavior would be the March 2018 port call visit by USS Carl Vinson to Da Nang, "the city where 3,500 Marines landed in March 1965 as the war's first American ground troops" (Maresca, 2018); or the 2015 decision of the Vietnamese government to start buying its military equipment supplies from the U.S. so as to limit Vietnam's dependence on China in this respect (Boudreau, 2015). Therefore, the current dynamic of the development of the U.S.Vietnam security relationship would attest to the growing resentment of Hanoi with the lack of reciprocity on the part of Beijing and the increased readiness to view expanding military-tomilitary ties with Washington as a legitimate form of balancing.

For its part, the international economic cooperation of Vietnam with both China and the United States would show Hanoi's focus on avoiding being entangled into the respective economic integration structures while drawing benefits from trade and investment, as the case may be. Vietnam's membership in the ASEAN, as effected in 1994, would serve as a starting point for the country's increasing openness to the global capitalist forms of international production, investment, and exchange, while China's similar rapprochement with the ASEAN 
in the mid-1990s would give impetus to further intensification of Sino-Vietnamese international economic cooperation in the reform era.

The dynamics of the U.S.-Vietnamese and the Sino-Vietnamese foreign trade growth would show a comparative equilibrium in Vietnam's openness to businesses registered in the two countries: while the volume of external trade between China and Vietnam had risen $\$ 30$ million to $\$ 20.8$ billion in 1991-2009, a similar increase in the U.S.-Vietnam trade was registered as well (from \$4.6 million to \$15.4 billion; Nguyen, 2016: 177). While in both cases Vietnam would definitely experience substantial trade deficits (Ikebe, 2013), one may argue that in the context of economic asymmetry, the Vietnamese state would try to offset the economic influence of China against that of the USA, and vice versa, thus eschewing any lopsided reliance on either of its major international trade partners. For Vietnam, the 2007 joining the World Trade Organization (WTO) would further imply the gradual turn in favor of closer relations with the United States (Boumelassa \& Valin, 2009: 13-42). Against that background, the Vietnamese leadership had committed to participating first in the TransPacific Partnership (TPP), and then the Comprehensive and Progressive Agreement for TransPacific Partnership (CPTPP), from 2008 on (Hoang \& Hoan, 2019). In fact, the 2019 CPTPP summit would be marked by a particular activism of the Vietnamese delegation (Hoang \& Hoan, 2019: 5), thereby reflecting the emphasis on fostering ties of complex interdependence with the U.S. and pro-Western states involved in this project as a counter-balance to China's projects of regional economic integration.

As for the One Belt One Road (OBOR) initiative, Vietnam would so far display a cautious approach by neither rejecting outright China's efforts aimed at expanding the transport and infrastructure cooperation networks provided for by this project to the territory of Vietnam. Nor being too eager in opening up to Beijing's offers of extended credit and investment cooperation (Experts, 2019). The problem of perceived vulnerability of Vietnam to a 'debt trap' arising out of too close cooperation with China in the context of the OBOR appear to play a preeminent role in that regard. Overall, Vietnam currently appears to try to keep China at arm's length as far as the question of the OBOR may be concerned, which is unlikely to further contribute to Beijing's appreciation of Hanoi's policies in that regard.

\section{Conclusion}

That said, the case of Vietnam would demonstrate how a middle power that was initially isolated in the international arena after the fall of its previous patron superpower, succeeded in furnishing a relatively stable (though hardly unblemished) triangular relationship with the United States of America and the People's Republic of China, to the extent that the balancing policies put into effect by the Vietnamese leadership proved successful in maintaining a middle position between the two extremes of aligning with either Washington or Beijing in the context of the regional system of international relations. However, presently, a certain inclination of Vietnam to focus on developing tighter connections with the U.S. proved to emerge, which may in turn lead to soured relations with the PRC. Nonetheless, the factor of ongoing ideological affinity and the apprehension caused by the prospects of the "peaceful evolution" as related above would make it unlikely that Vietnam might ever become a fully-fledged ally of the United States against China, while the evident tension concerning the access to natural resources of the South China Sea would have the same effect with regard to the possibility of Vietnam joining forces with China against the USA. Hence, such an equilibrium of competing 
A 'Triangular' Relationship with the Great Powers: The Case of the post-Cold War Vietnam Balancing versus China and the USA by Leonid L. Kyianytsia

claims and ideologically motivated concerns will likely contribute to maintaining the present state of affairs for the time to come.

\section{References}

Abuza, Zachary. (1996) International relations theory and Vietnam. Contemporary Southeast Asia, Vol. 17, No. 4, 406-419.

Battle for Ukraine: How the West lost Putin. (2015) Financial Times, 2 February 2015. Available at: https://www.ft.com/content/e3ace220-a252-11e4-9630-00144feab7de

Baviera, Aileen S. P. (2011) Accommodation with hedging: Southeast Asia's changing perspectives toward China. In Herbert S. Yee (ed.). China's rise - Threat or opportunity? London: Routledge, 176-190.

Boudreau, John. (2015) Vietnam goes shopping for U.S. military hardware. Bloomberg News, 14 May 2015. Available at: https://www.bloomberg.com/news/articles/2015-05-13/ vietnam-turns-to-u-s-to-buy-weapons-40-years-after-war-s-end

Boumelassa, Housseinand Hugo Valin. (2009) Vietnam's accession to the WTO: Ex post evaluation in a dynamic perspective. Économieinternationale, No. 118, 13-42.

Elliott, David W. P. (2012) Changing worlds: Vietnam's transition from Cold War to globalization. Oxford University Press.

Experts warn of 'debt-trap' for Vietnam in Belt and Road Initiative as China bids for projects. (2019) Radio Free Asia. Available at: https://www.rfa.org/english/news/vietnam/bri05222019152925.html

Freyberg-Inan, Annette. (2004) What moves man: The realist theory of international relations and its judgment of human nature. Albany, NY: State University of New York.

Galbreath, David J. (2008) International regimes and organizations. In Trevor C. Salmon and Marc F. Imber (eds.). Issues in international relations. $2^{\text {nd }}$ edition. New York, NY: Routledge, 121-135.

Hiebert, Murray, Phuong Nguyen and Gregory B. Poling (2014) A new era in U.S.-Vietnam relations: Deepening ties two decades after normalization. New York, NY: Rowman \& Littlefield.

Hoang, Nguyen Huy and Truong QuangHoan (2019). Vietnam and the CPTPP: Achievements and challenges. ISEAS Perspective, No. 41, 1-8. https://www.iseas.edu.sg/images/pdf/ ISEAS_Perspective_2019_41.pdf

Ikebe, Ryo. (2013) Economic disparity of the China-Vietnam economic border regions. In Masami Ishida (ed.). Border economies in the Greater Mekong sub-region. Basingstoke: Palgrave Macmillan, 250-278.

Jahn, Beate. (2013) Liberal internationalism: Theory, history, practice. Basingstoke: Palgrave Macmillan.

Keohane, Robert O. (2012) Twenty years of institutional liberalism. International Relations, Vol. 26, No. 2, 125-138.

Korab-Karpowicz, W. Julian. (2010) Political realism in international relations. Stanford Encyclopedia of Philosophy.Available at: https://plato.stanford.edu/entries/realismintl-relations/\#HansMorgRealPrin

Lohman, Walter, Lewis M. Stern, and William Jordan. (2012) U.S.-Vietnam defense relations: Investing in strategic alignment. Backgrounder (The Heritage Foundation), No. 2707, 18 July 2012, pp. 3-5. 
Manyin, Mark E. (2008) U.S.-Vietnam relations: Background and issues for Congress. Congressional Research Service, 31 October 2008. https://fas.org/sgp/crs/row/ RL33316.pdf

Manyin, Mark E. (2010) U.S.-Vietnam relations in 2010: Current issues and implications for U.S. policy. Congressional Research Service, 6 August 2010. https://apps.dtic.mil/dtic/ tr/fulltext/u2/a530565.pdf

Manyin, Mark E. (2012) U.S.-Vietnam relations in 2012: Current issues and implications for U.S. policy. Congressional Research Service, 18 May 2012. https://www.hsdl. org/?view\&did=710928

Maresca, Thomas. (2018) U.S. 'supercarrier' USS Carl Vinson makes historic port call in Vietnam. USA Today, 23 March 2018. https://eu.usatoday.com/story/news/ world/2018/03/05/uss-carl-vinson-arrives-vietnam/394324002

Mearsheimer, John J. (2001) The tragedy of great power politics. New York, NY: W.W. Norton and Company.

Mearsheimer, John J. (2014) Why the Ukraine Crisis is the West's fault. Foreign Affairs, September/October 2014. https://www.foreignaffairs.com/articles/russiafsu/2014-08-18/why-ukraine-crisis-west-s-fault

Nguyen, Thanh Trung. (2016) Accommodating the dragon: Vietnam's enduring asymmetric entanglements with China. Doctoral dissertation, Hong Kong Baptist University.

Odgaard, Liselotte. (2007) The balance of power in Asia-Pacific security: US-China policies on regional order. London: Routledge.

Parent, Joseph and Sebastian Rosato. (2015) Balancing in neorealism. International Security, Vol. 40, No. 2, 51-86.

Shoji, Tomotaka. (2018) Vietnam's security cooperation with the United States: Historical background, present and future outlook. NIDS Journal of Defense and Security, 19 December 2018. http://www.nids.mod.go.jp/english/publication/kiyo/pdf/2018/ bulletin_e2018_2.pdf

Sterling-Folker, Jennifer. (2002) Theories of international cooperation and the primacy of anarchy: Explaining U.S. international monetary policy-making after Bretton Woods. Albany, NY: State University of New York Press.

Stern, Lewis M. (2005) Defense relations between the United States and Vietnam: The process of normalization, 1977-2003. Jefferson, N.C: McFarland \& Co.

Thayer, Carl. (2011) The tyranny of geography: Vietnamese strategies to constrain China in the South China Sea. Contemporary Southeast Asia, Vol. 33, No. 3, 348-369.

Thayer, Carl. (2014) China-Vietnam defense hotline agreed: What next?The Diplomat, 20 October 2014. Available at: https://thediplomat.com/2014/10/china-vietnam-defensehotline-agreed-what-next

Vu, Tung Nguyen. (2011) Vietnam's security challenges: Hanoi's new approach to national security and implications to defense and foreign policies. In The National Institute for Defense Studies, Japan. Asia Pacific countries security outlook and its implications for the defense sector. NDIS Joint Research Studies, No. 5, 107-122.

Wong, Kam C. (2002) Who owns the Spratly Islands? The case of China and Vietnam. China Report, Vol. 38, No. 3, 345-358. 